\title{
KAJIAN INVESTASI SISTEM INFORMASI BERDASARKAN DOMAIN BISNIS PADA UNIVERSITAS $X$
}

\author{
Leo Willyanto Santoso ${ }^{1}$, Yulia ${ }^{2}$, Aldy Wirawan ${ }^{3}$ \\ ${ }^{1,2,3}$ Progam Studi Teknik Informatika, Fakultas Teknologi Industri, Universitas Kristen Petra \\ Jl. Siwalankerto 121-131, Surabaya 60236, Indonesia \\ E-mail: leow@petra.ac.id, yulia@petra.ac.id
}

\begin{abstract}
Abstrak: Untuk memperoleh sistem dan teknologi informasi yang handal diperlukan investasi yang tepat atas sistem dan teknologi informasi yang dijalankan oleh perusahaan agar besarnya manfaat dari investasi sistem dan teknologi informasi tersebut sepadan dengan tingginya biaya yang diinvestasikan untuk membangun aplikasi tersebut. Universitas ' $\mathrm{X}$ ' telah melakukan investasi teknologi dan sistem informasi akademik untuk menunjang proses bisnisnya. Dirasa perlu untuk melakukan analisa keunggulan dan kelemahan dari investasi sistem dan teknologi tersebut, serta menilai apakah investasi tersebut telah menunjang proses bisnis organisasi. Selain itu, mengetahui nilai-nilai ekonomis dari investasi SI/TI dan perhitungan ROI merupakan hal yang krusial. Tujuan penelitian adalah untuk menganalisis dan menilai sejauh mana kesuksesan investasi sistem informasi yang telah dilakukan oleh perusahaan dengan menggunakan analisa pada domain bisnis metode Information Economics (IE). Metode penelitian yang digunakan adalah kepustakaan, survey, wawancara, kuesioner, studi dokumentasi dan metode analisis. Pada akhir penelitian, telah berhasil dibuat analisa investasi Sistem Informasi Akademik Universitas 'X', berupa perhitungan ROI dan IE Score serta tools untuk menyimpan data project serta hasil perhitungan ROI dan IE Score.
\end{abstract}

Kata kunci: Investasi, Sistem Informasi, information economics, domain bisnis

\begin{abstract}
Appropriate investment on information technology is needed to obtain the information technology systems that are reliable. University ' $X$ ' has decided to do technology investments by developing academic information systems to support business processes. It is necessary to analyze the advantages and disadvantages of the systems and technology investments, and assess whether the investment has been supporting the organization's business processes . In addition, knowing the economic value of investments/ IT and ROI calculation is crucial. The purpose of the study is to analyze and assess the extent to which the success of information systems investments made by the company by using a business domain analysis method on Information Economics (IE). The method used was the literature research, surveys, interviews, questionnaires, documentation studies and methods of analysis. At the end of the study, it has successfully made the investment analysis of the University Academic Information Systems, a ROI calculation and IE Score as well as tools for storing project data and calculation results and ROI Score
\end{abstract}

Keywords: Investment, Information System, Information Economics, Business Domain

\section{PENDAHULUAN}

Era teknologi informasi (TI) semakin berkembang dan mendominasi kehidupan sehari-hari. Hal tersebut semakin mendorong manusia untuk terus dapat memanfaatkan perkembangan teknologi dalam kehidupan. Teknologi yang ada saat ini telah banyak digunakan oleh berbagai organisasi untuk mendukung proses bisnis untuk meningkatakn efisiensi dan efektifitas organisasi. Oleh sebab itu, semakin banyak organisasi yang berlomba-lomba untuk melakukan investasi demi mengoptimalkan sumber daya yang mereka miliki.

Besarnya nilai nominal yang harus dikeluarkan untuk melakukan investasi Sistem Informasi (SI) membuat banyak pihak mulai bertanya-tanya, bagaimana cara memperkirakan seberapa besar investasi tersebut memberikan manfaat bagi organisasi. Fakta menyatakan bahwa manfaat investasi SI dapat berupa yang terhitung (tangible) maupun yang tidak terhitung (intangible). Manfaat ini juga ada yang dapat dirasakan secara langsung dan ada juga yang hanya dapat dirasakan setelah jangka waktu tertentu. Hal ini menyebabkan banyak organisasi mengalami kesulitan bagaimana menghitung nilai investasi SI dikaitkan dengan manfaat yang dihasilkan.

Nilai uang dan waktu uang sangat berperan besar untuk perhitungan manfaat yang dapat diperoleh dalam melakukan investasi SI. Hal yang diharapkan organisasi adalah bagaimana mendapatkan 
keuntungan jika mengeluarkan sejumlah uang (investasi) pada investasi SI yang mereka lakukan, yang hasilnya dapat dinikmati dimasa kini dan dimasa yang akan datang, dengan harapan nilai uangnya bertambah.

Dalam melakukan investasi yang terpenting adalah berapa besar keuntungan yang diperoleh, kapan return on investment (ROI), dan berapa lama waktu yang dibutuhkan untuk mencapai ROI. Dalam investasi SI, pengukuran ROI terutama dalam penentuan keuntungan, baik tangibel maupun intangible sulit untuk dilakukan, terutama penentuan parameter dalam perhitungan keuntungan intangible-nya.

Universitas ' $\mathrm{X}$ ' merupakan universitas yang memanfaatkan SI untuk mendukung proses bisnis organisasi secara intensif, dimana hal ini sesuai dengan misi universitas, dengan menjadi kampus berbasis teknologi informasi. Universitas ' $\mathrm{X}$ ' harus memperhitungkan nilai-nilai ekonomis yang akan diperoleh dari investasi SI pada tahun yang sedang berjalan dan tahun-tahun selanjutnya. Berdasarkan hal-hal di atas, maka dilakukan evaluasi terhadap investasi yang sudah dilakukan oleh Universitas ' $\mathrm{X}$ '.

\section{INFORMATION ECONOMICS}

Information Economics (IE) merupakan sekumpulan peralatan (tools) komputasional untuk mengkuantifikasi biaya dan manfaat dari suatu proyek TI $[5,7]$. Metode ini diperkenalkan Marilyn M. Parker bersama timnya dari IBM pada tahun 1985, yang digunakan mengkuantifikasikan biaya (cost) dan manfaat (benefit) dari proyek TI.

Metode IE ini merupakan pengembangan dari Cost Benefit Analysis (CBA) tradisional. IE dikembangkan karena adanya kebutuhan dari pihak perusahaan untuk mengetahui bagaimana dampak ekonomis investasi TI terhadap perusahaan.

IE digunakan untuk menganalisis biaya dan manfaat, mengkuantifikasi biaya proyek TI yang hasilnya diharapkan dapat memberikan manfaat kepada perusahaan [5]. Dasar dari IE adalah nilai (value) yang dapat dikatakan sebagai suatu ukuran dan biaya (cost) yang dikeluarkan oleh perusahaan, yang dikaitkan dengan kemajuan bisnis perusahaan. IE secara eksplisit mengevaluasi alternatif investasi sistem informasi dengan mengidentifikasi dan lalu mengevaluasi (evaluating), pemberian skor (scoring), dan pemberian peringkat (ranking), faktor positif (nilai) dan faktor negatif (risiko atau ketidakpastian) yang potensial dari sekumpulan kandidat investasi.

Perhitungan nilai ekonomis merupakan dasar pertimbangan dalam proses pengambilan keputusan pada pengajuan investasi untuk sebuah pembangunan sistem. Biaya yang dievaluasi mencakup biaya pengadaan perangkat keras, pembelian perangkat lunak, seluruh biaya perawatan dan biaya tenaga kerja. Biaya ini harus dijustifikasikan karena masingmasing investasi itu memiliki karakteristik yang berbeda terhadap nilai dan risiko [6].

Latar belakang yang melandasi dibutuhkannya IE adalah untuk mengevaluasi manfaat yang ditimbulkan oleh penerapan TI, mengingat kebutuhan akan penerapan TI sudah tidak dapat ditunda lagi bagi perusahaan. Bahkan sekarang ini, peranan TI merupakan kunci utama bagi suatu perusahaan dalam melakukan persaingan. Dalam mengimplementasikan TI, setiap perusahaan mengaplikasikan dengan cara yang tidak selalu sama, sehingga nilai TI dan manfaat yang diperoleh perusahaan akan berbeda antara satu dengan yang lain.

Sumber daya perusahaan uang digunakan dalam menerapkan TI terbatas jumlahnya sehingga harus dimanfaatkan seefisien dan seefektif mugkin [3, 4]. Perusahaan perlu melakukan keputusan untuk mengalokasikan sumber daya dengan cara yang paling efektif dengan pertimbangan hasil yang diperoleh baik secara langsung maupun tidak langsung atas alokasi biaya yang dikeluarkan $[1,2]$.

Kegiatan dalam suatu perusahaan dapat dibagi menjadi dua bagian besar, yaitu kegiatan bisnis dan kegiatan teknologi yang mendukung bisnis [5]. Istilah "domain" sendiri digunakan untuk mengkarakteristikan kedua kegiatan yang berbeda itu. Dua domain inilah yang menjadi model dari IE. Pada makalah ini, peneliti berfokus pada domain bisnis.

Dari sudut pandang domain bisnis, nilai diciptakan dengan menggunakan TI, misalnya adanya peningkatan pendapatan, pengurangan biaya, dan peningkatan efektivitas [7].

\section{DOMAIN BISNIS - INFORMATION ECONOMICS}

Faktor-faktor dalam domain bisnis dibagi menjadi lima kategori, yaitu: Financial Values, Strategic Values, Stakeholder Values, Competition Strategy Risk, dan Organizational Risk and Uncertainty.

\section{Financial Values}

Financial Values adalah manfaat yang dapat diukur dengan menggunakan dasar-dasar akuntansi. Nilai yang terdapat dalam domain bisnis adalah business-based financial values (nilai keuangan berbasis bisnis). Dalam business-based financial values, Manfaat dan biaya yang diharapkan dalam implementasi suatu sistem harus ditentukan, sedangkan untuk hubungan antara manfaat dengan biaya ditentukan dengan Return of Investment (ROI) 
sederhana, Net Present Value (NPV), Internal Rate of Return (IRR), Profitability Index, Payback Period, Present worth serta Probability of Attainment.

Terdapat dua tipe dari biaya dan manfaat yaitu tangible, dikarakteristikan dengan diketahui dan dapat diukut dalam nilai rupiah dan berpengaruh dalan aliran kas, dan intangible dikarakteristikan sebagai suatu yang sangat sulit dan tidak mungkin diukur dalam nilai rupiah. Business-based Financial Values memperhitungkan biaya dan manfaat tangible dan quasi tangible.

\section{Strategic Values}

Strategic Values adalah strategi yang menghasilkan nilai untuk kepentingan bisnis organisasi. Strategic Values pada domain bisnis adalah Strategic Match, Competitive Advantage, Competitive Response dan Management Information for Critical Success Factor.

Strategic Values berfokus pada pencapaian specific market, strategi pelanggan atau produk (strategic match), menciptakan pasar yang baru atau meningkatkan pendapatan (competitive advantage), dan melindungi pangsa pasar yang ada sekarang (competitive response). Sebagai tambahan, kelompok nilai ini meliputi ketersediaan dan kualitas dari informasi yang digunakan untuk proses pengambilan keputusan yaitu Management Information for CSFs. Secara bersamaan nilai-nilai strategis ini mewaliki strategic face perusahaan untuk pasar (market) dan pemegang saham.

Strategic Match menyediakan metode untuk meningkatkan skor dari aplikasi yang inovatif secara langsung memberikan dukungan bagi pencapaian tujuan bisnis. Penekanan terdapat juga pada hubungan yang erat antara TI dan perencanaan bisnis, serta penilaian derajat potensi dari proyek terhadap pencapaian strategi bisnis. Strategic Match menaksir nilai tujuan jangka panjang dan mensyaratkan adanya eksistensi yang terwujud. Skor pada strategic match berkisar antara 0 (tidak mempunyai hungungan dengan tujuan strategi bisnis yang ada sekarang) sampai 5 (memiliki hubungan langsung).

Competitive Advantage mengevaluasi adanya pertukaran data antara organisasi dengan para pemasok, distributor, atau unit kerja lain dalam kaitannya untuk meningkatan kompetensi organisasi. Nilai tersebut dapat diperoleh dengan adanya kesediaan dari organisasi untuk mengubah struktur industri atau sistem, meningkatkan posisi organisasi dalam bisnis yang ada, dan menciptakan kesempatan bisnis yang baru. Terdapat tiga tujuan dasar yang harus dilakukan perusahaan untuk mendapatkan keuntungan kompetitif, yaitu: Perusahaan harus memposisikan diri dalam struktur industri. Perusahaan harus mendukung tindakan-tindakan yang akan mengubah derajat dimana pembeli, pemasok, pendatang baru, dan produk pengganti atau para pesaing berpengaruh dalam kompetisi. Harus mengembangkan posisi organisasi pada bisnis yang sudah eksis. Perusahaan harus mendukung tindakan-tindakan yang dapat membedakan produk atau pelayanan yang diberikan oleh perusahaan atau mengubah cakupan kompetitif dari bisnisnya. Perusahaan harus menciptakan kesempatan bisnis baru. Ada beberapa cara yang dapat memberikan kontribusi untuk mendapakan keuntungan kompetitif, termasuk penggunaan TI untuk menjual produk/jasa atau menggunakan informasi internal untuk memproses kemampuan memulai lini bisnis baru. Dalam melakukan penilaian Competitive Advantage, maka terdapat tiga strategi utama yang harus dipertimbangkan implementasinya. Pertama, cost leadership, termasuk didalamnya cost avoidance, pengurangan biaya, serta identifikasi dan eksploitasi sumber yang ada sebagai cost advantage, kedua, diferensiasi (keunikan produk) dan ketiga, fokus yang jelas meliputi penentuan segmentasi target dari pasar potensial. Skor yang dihasilkan tergantung dari derajat nilai yang disumbangkan proyek terhadap organisasi dengan peningkatan kemampuan berkompetisi. Dengan kata lain, memuaskan perhatian pada manfaat kompetitif yang dihasilkan proyek.

Competitive Response mengukur derajat kegagalan dalam memenuhi keberhasilan yang diharapkan di awalm yang dapat menyebabkan kegagalan pesaing terhadap perusahaan. Competitive Response meliputi risiko kehilangan pasar karena pesaing telah menyediakan jasa, produk, atau pertukaran data maupun kemampuan yang dibutuhkan industri serta otoritas yang diberikan sebagai kondisi aktivitas bisnis yang berkelanjutan

Management Information for Critical Success Factor berfikus pada aktivitas internal yang secara langsung mempengaruhi produk dan pelanggan eksternal. Management Information for Critical Success Factor memperkirakan kontribusi langkahlangkah yang diambil terhadap kebutuhan informasi manajemen untuk aktivitas yang kritis. Informasi dalam dukungannya pada CSFs bisnis mencerminkan derajat dimana tindakan menyediakan informasi manajemen pada kunci aktivitas dari perusahaan atau lini bisnis.

\section{Stakeholder Values}

Stakeholder Values adalah nilai yang mempresentasikan strategi yang berfokus pada dukungan terhadap eksternal, pelanggan dan produk. Adapun yang merupakan stakeholder values pada domain 
bisnis adalah services and quality, agility, learning and empowerment, cycle time, environmental quality, dan mass costomization.

Dalam services and quality, penyampaian produk dan pelayanan yang benar, bebas dari kesalahan dan tepat waktu dengan harga yang sesuai adalah indikator dan kriteria pengukuran yang dipertimbangkan oleh para stakeholder. Suatu proses perbaikan pelayanan dan tingkat kualitas adalah strategi organisasi, yang seharusnya dikenali sebagai prioritas investasi yang memiliki efek sinergis dan kumulatif.

Agility, Learning, and Empowerment secara berkesinambungan memusatkan perhatian pada peningkatan fleksibilitas, intelijen dan kemampuan adaptasi untuk mengubah kedua faktor penting organisasi yaitu tenaga kerja dan proses bisnis. Lebih jauh lagi, memperkuat investasi organisasi dengan menyediakan informasi yang diperlukan, pertanggungjawaban dan otoritas dalam pengambilan keputusan.

Dalam cycle time, Peningkatan cycle time adalah suatu keharusan dalam berkompetisi. Cycle time berfokus pada semua elemen yang masih dalam proses, mulai dari menyelenggarakan budaya inovatif untuk memacu ide baru melalui pengembangan dan produksi yang sukses dan penyalurannya ke konsumen dengan tepat waktu sampai pada pembangunan standar industri baru atau praktik terbaik.

Environmental Quality menjadi penggabungan yang umum untuk beberapa stakeholders perusahaan. Dengan adanya environmental quality maka pekerja dapat bekerja pada lingkungan yang bersih, pelanggan menunjukkan kepeduluan tentang keamanan dari produk yang digunakan, dan investor menunjukan kepedulian tentang pertanggung-jawaban (liability) potensial sebagai hasil dari produksi produk.

Mass customization mensyaratkan kemampuan untuk memproduksi lebih cepat pada keanekaragaman produk yang lebih besar melalui costumization. Prinsip mass customization dapat juga diterapkan untuk personalisasi dari pelayanan, tidak hanya untuk produksi barang-barang konsumer (consumer goods).

\section{Competitive Strategy Risks}

Manajemen organisasi harus mendefinisikan dengan jelas respon terhadap risiko dan ketidakpatian lalu mengkomunikasikan posisi tersebut kepada semua elemen dari organisasi. Risiko dan ketidakpastian yang ada sangat mempengaruhi bahkan ikut menentukan keseluruhan strategi suskes.

Business Strategy Risk mencerminkan level kesuksesan strategi bisnis itu sendiri, memberikan pasar yang dinamis, perusahaan yang dinamis, dan waktu. Dari sudut pandang TI, proyek yang berhubungan dengan strategi bisnis berisiko adalah faktor yang dipertimbangkan dalam perhitungan keuntungan finansial dan dapat ditemui sebagai bagian dari perhitungan pengaruh ekonomi. Yang perlu diperhatikan adalah risiko yang berhubungan dengan nilai atas keuntungan intangible harus dipisahkan dalam faktor yang berbeda. Business strategy risk berfokus pada risiko jangka panjang di sekitar strategi kompetitif dan merubah lingkungan pasar dengan tujuan merubah hubungan pemasokpelanggan, political realignment, demographic trends, atau regulatory trends.

\section{Organizational Risk and Uncertainty}

Bagian ini mempunyai fokus pada usaha internal. Pada domain bisnis, organizational risk and uncertainty merupakan business organization risk. Business Organization Risk berfokus pada kemampuan organisasi dalam melakukan perubahan yang diperlukan untuk proyek, yaitu kebutuhan pengguna dan bisnis.

\section{HASIL DAN PEMBAHASAN}

Pertama-tama dilakukan pembobotan nilai korporat organisasi berdasarkan dari hasil kuesioner yang telah diisi oleh pihak-pihak yang terkait langsung dengan pengembangan proyek SI Akademik pada Universitas X.

Pada subbab ini dilakukan pembahasan baik nilai maupun risiko yang terdapat pada domain bisnis, dimana proses penilaian ini didasarkan atas kesesuaian antara rencana penerapan SI Akademik dengan keadaan Universitas X saat ini. Penilaian pada domain bisnis terdiri dari 5 kategori, yaitu: Financial Values, Strategic Values, Stakeholder Values, Competitive Strategic Risk, dan Organization Risk and Uncertainty.

\section{Financial Values}

Return on Investment (ROI) adalah nilai finansial yang berdasarkan kepada penilaian bisnis dan teknologi yang saling berhubungan untuk memberikan nilai akhir kepada ROI pada lembar kerja dampak ekonomis. Dari hasil perhitungan dengan menggunakan lembar kerja dampak ekonomis, dapat dilihat adanya bobot ROI yaitu mendapatkan skor +1 . Skor tersebut didapat dari hasil penilaian dengan menggunakan lembar kerja dampak ekonomis pada subbab sebelumnya. ROI mendapat nilai 1 karena ROI yang didapat sebesar $138,4268056 \%$. 


\section{Strategic Values}

Pada Strategic Match, evaluator ini berhubungan dengan sejauh mana sebuah proyek teknologi informasi yaitu SI Akademik dapat mendukung dan membatu atau selaras dengan kegiatan Universitas $\mathrm{X}$. Universitas X mengharapkan dengan diterapkannya SI Akademik maka dapat meningkatkan produktivitas dan performa kerja sumber daya manusianya sehingga dapat menunjang pencapaian tujuan. Setelah dilakukan wawancara dan kuesioner penilaian yang telah dibagikan diperoleh skor $+4,3$. Dengan skor $+4,3$ maka dapat disimpulkan SI Akademik sudah cukup menunjang kebutuhan Universitas $\mathrm{X}$ dan mampu meningkatkan produktivitas sumber daya manusianya.

Competitive Advantage berfokus pada sejauh mana sebuah proyek teknologi informasi atau sistem informasi manajemen mendukung untuk berusaha mempertahankan atau meningkatakan keunggulan kompetitifnya. Dari kuesioner yang dibagikan mendapat jawaban skor $+3,7$. Dengan skor yang diberikan berarti pembangunan proyek SI Akademik sudah cukup memberikan peningkatan posisi kompetitif untuk Universitas X.

Competitive Response berhubungan dengan kerugian karena penundaan implementasi proyek TI. Penundaan ini dapat mengakibatkan terjadinya kegagalan kompetitif bagi perusahaan. Tetapi semuanya dikembalikan lagi kepada proyek TI tersebut apakah merupakan proyek yang sangat penting dan kritis bagi Universitas $X$ atau proyek tidak terlalu berakibat buruk jika pengimplementasiannya ditunda. Nilai untuk proyek SI Akademik berdasarkan kuesioner yang diberikan skor $+4,7$ karena proyek TI ini dianggap sangat dibutuhkan untuk menunjang kegiatan kemahasiswaan di Universitas X. Karena jika terjadi penundaan akan ada dampak yang cukup buruk untuk kegiatan kemahasiswaan. Salah satu contohnya adalah jika ada penundaan SI Akademik maka perhitungan untuk hasil PRS akan memerlukan waktu lebih lama untuk prosesnya.

Pada Management Information for CSF, faktor ini berhubungan dengan kemampuan proyek aplikasi teknologi informasi dalam menyediakan informasi secara cepat dan akurat untuk mendukung aktivitas utama dalam perusahaan.

Informasi merupakan hal yang sangat penting bagi organisasi. Tersedianya manajemen informasi yang tepat dan akurat dapat menjadi suatu keunggulan. Informasi yang terdistribusi dengan baik dan lancar akan membawa dampak positif bagi Universitas X. Salah satunya adalah meningkatan produktivitas kerja dan cepat tanggap dengan situasi yang sedang terjadi sekarang ini. Faktor ini diberi skor
+5 karena dengan adanya SI Akademik maka informasi yang diminta dapat diberikan langsung dengan cara melihat langsung dari SI Akademik.

\section{Stakeholder Values}

Pada Service and Quality, penilaian faktor ini dilakukan untuk menghitung seberapa besar dampak proyek TI terhadap peningkatan pelayanan dan kualitas yang akan dicapai. Faktor ini berhubungan dengan kepuasan pengguna.

Kualitas dan pelayanan faktor yang penting karena Universitas $\mathrm{X}$ bergerak pada bidang jasa. Dengan adanya pembangunan proyek TI maka dapat meningkatkan faktor pelayanan dan kualitas Universitas $\mathrm{X}$ di mata mahasiswa sebagai penggunanya. Faktor ini diberi nilai +5 didapat dari kuesioner karena dengan adanya SI Akademik ini lebih membantu mahasiswa dalam mendapatkan informasi. Dengan adanya SI Akademik mahasiswa dapat melihat datanya kapanpun dan dimanapun mahasiswa tersebut berada. Dengan demikian pelayanan dan kualitas yang dicapai cukup tinggi.

Environment Quality berhubungan dengan seberapa besar kualitas lingkungan yang menjadi dambaan setiap stakeholder yang merupakan tema strategis yang akan terus berlangsung di masa depan. Pembangunan proyek TI berhubungan secara tidak langsung dengan isu lingkungan tertentu. Penundaan proyek TI ini akan mengakibatkan keuntungan kompetitif sedikit berkurang maka faktor ini memperoleh skor +4 yang didapat dari hasil kuesioner.

Agility, Learning and Empowerment berhubungan dengan kemampuan karyawan untuk menyesuaikan diri dengan situasi yang baru akibat pengimplentasian teknologi informasi yang baru. Pihak manajemen beranggapan bahwa para karyawan tidak terlalu mengalami kesuliatan yang berarti dalam beradaptasi dengan SI Akademik, karyawan cukup dapat menyesuaikan diri dengan SI Akademik sehingga faktor ini mendapat skor +4 . Karyawan dapat dengan cepat beradaptasi, hal ini dikarenakan sebelum menggunakan SI Akademik ini sudah ada sistem yang membantu. Hanya perlu sedikit beradaptasi dengan penggunaan SI Akademik yang baru sehingga penilaian hasil kuesioner mendapat skor $+4,3$.

Cycle Time berhubungan dengan peningkatan waktu proses setelah implementasi sistem yang baru. Penilaian faktor ini dilakukan untuk menghitung seberapa besar dampak dari implementasi proyek terhadap waktu semua komponen atau elemen yang terlibat dalam suatu proses bisnis. Dengan adanya implementasi SI Akademik dapat menciptakan peningkatan dalam efektivitas dan efisiensi beberapa 
proses bisnis yang ada. Peningkatan proses ini mampu melebihi dari beberapa pesaing utama yang ada. Faktor ini mendapatkan skor +4 . Meskipun tidak ada percepatan waktu proses yang terjadi karena sebelum menggunakan SI Akademik BAAk sudah menggunakan sistem lama, tetapi tetap saja SI Akademik memberikan dampak yang besar untuk percepatan waktu proses. Karena jika SI Akademik mengalami penundaan/dihilangkan maka sistem tidak akan berjalan dan terintregasi dengan baik. Sehingga didapatkan nilai +4 dari hasil kuesioner.

Mass Customization berhubungan dengan kemampuan untuk menghasilkan berbagai macam variasi produk yang lebih cepat melalui penyesuaian. Universitas $\mathrm{X}$ menganggap bahwa pembangunan proyek SI Akademik akan memfasilitasi sebuah mass customization yang cukup dalam hal-hal diatas, dan secara signifikan meningkatkan posisi kompetitif Universitas $\mathrm{X}$ ke sebuah tingkat keadaan yang menanggapi pesaing yang banyak. Faktor ini diberi skor +4 .

\section{Competitive Strategy Risk}

Business Strategy Risk berkaitan dengan risiko bisnis jangka panjang yang mungkin timbul karena adanya implementasi suatu proyek TI serta dapat mempengaruhi strategi yang sudah ada. Pembangunan proyek SI Akademik memiliki risiko yang tinggi karena membutuhkan kekuatan bersaing yang tinggi. Karena memiliki risiko yang tinggi karena membutuhkan daya saing yang tinggi dan membutuhkan cukup banyak hubungan dengan user maka hasil kuesioner memberikan nilai $-4,7$

\section{Organizational Strategy Risk and Uncertainty Business Organization Risk}

Faktor ini berfokus pada derajat dimana organisasi mampu membawa perubahan yang diperlukan oleh suatu proyek TI. SI Akademik dinilai mampu membawa perubahan yang diperlukan sehingga memiliki risiko yang cukup tinggi bagi proses bisnis sebuah organisasi. Maka dari itu hasil kuesioner memberikan nilai yang cukup tinggi yaitu $-4,7$.

\section{Simple Return on Investment (ROI)}

Simple ROI adalah rasio pendapatan bersih ratarata proyek terhadap investasi internal proyek itu. Metode ini sangat baik untuk proyek pemrosesan data atau sistem informasi. Biaya implementasi dan operasional serta manfaat yang diharapkan akan ditentukan untuk bertahun-tahun mendatang. Titik ketika manfaat akumulatif melebihi akumulatif biaya adalah titik di mana dasar ROI didapatkan. Setelah menganalisa dan menghitung biaya investasi, biaya berjalan, value linking, value acceleration, dan value restructuring maka dibuat simple return on investment dengan menggunakan lembar kerja dampak ekonomis seperti pada Gambar 3.

Dan Perhitungan NPV IRR adalah sebagai berikut:

$\mathrm{NPV}=$ Rp. 2.376 .342 .985

$\mathrm{IRR}=13.37386902$

Setelah dilakukan pembobotan dan penilaian maka dibuat sebuah tabel IE Scorecard seperti pada Tabel 1.

Tabel 1. IE Scorecard

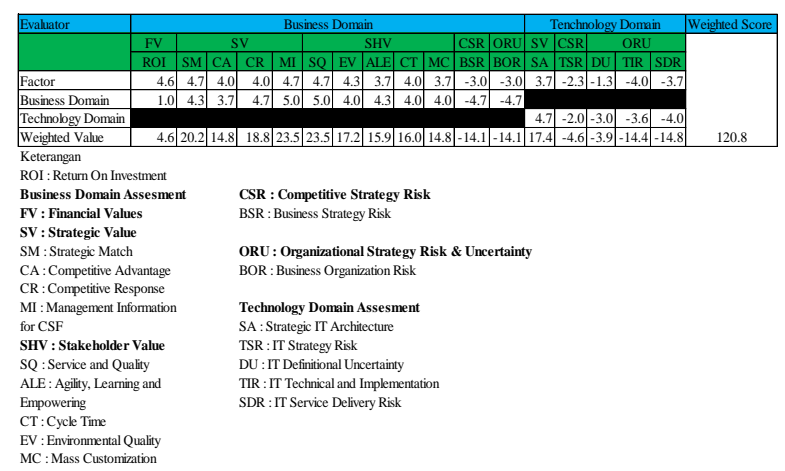

Setelah melakukan perhitungan Weighted Score dan mendapatkan nilainya maka dirancang suatu tabel predikat untuk mengkategorikan skor kelayakan suatu proyek. Tabel predikat dapat dilihat pada Tabel 2.

Tabel 2. Predikat

\begin{tabular}{ll}
\hline Kategori Skor & Predikat \\
\hline $164-210$ & Sangat Baik \\
$109-163$ & Baik \\
$54-108$ & Cukup \\
$(-1)-53$ & Kurang \\
$(-65)-(-2)$ & Sangat Kurang \\
\hline
\end{tabular}

\section{KESIMPULAN DAN SARAN}

\section{Kesimpulan}

Dengan menggunakan Traditional cost and benefit analysis diperoleh ROI sebesar $138,4268056 \%$ dari total estimasi arus kas bersih selama lima tahun sebesar Rp. 4.285.680.058,-. Hal ini memperlihatkan tidak ada keuntungan finansial langsung sehingga proyek kelihatan merugi apalagi ROI bernilai negatif.

Keseluruhan hasil yang diperoleh dari kuesioner diolah di Information Economics Scorecard sehingga menghasilkan suatu nilai proyek sebesar 120,8 dengan bantuan tabel predikat yang telah dirancang, 
maka nilai proyek 120,8 mendapat predikat baik. Predikat baik ini menunjukan bahwa Sistem Informasi layak untuk dikembangkan dan bermanfaat.

\section{Saran Pengembangan}

Information Economics memang telah membuktikan bahwa sebuah investasi teknologi informasi tidak cukup dinilai secara matematis saja. Ada nilainilai yang tidak dapat dikuantifikasikan, yang merupakan nilai unik di dalam domain teknologi yang perlu dipertimbangkan.

\section{DAFTAR PUSTAKA}

[1] Fitzpatrick, E.W. 2005, Planning and Implementing IT Portfolio Management: Maximizing the Return on Information Technology Investments, IT Economics Corporation.
[2] Hayes, R.H., Pisano, G.P., Upton, D.M. dan Wheelwright, S.C., 2005, Operations, Strategy, and Technology: Pursuing the Competitive Edge. Wiley.

[3] McLeod, R. dan Schell, G., 2006, Management Information Systems, $10^{\text {th }}$ Ed., Prentice Hall.

[4] O'Brien, J., 2005, Introduction to Information System. $12^{\text {th }}$ Ed., McGraw. Hill, New York.

[5] Parker, M.M., Benson, R.J., Trainor, H.E., 1988, Information Economics: Linking Business Performance to Information Technology, Prentice Hall, New Jersey.

[6] Remenyi, D., Money, A., Sherwood-Smith, M., dan Irani, Z., 2000, The Effective Measurement and Management of IT Costs and Benefits, $2^{\text {nd }}$ Ed., Butterworth-Heinemann, Britain.

[7] Yulia, 2005, Kajian Kelayakan Investasi Proyek Teknologi Informasi dengan Menggunakan Metode Information Economics, Jurnal Informatika. Vol 6, No 2, pp 110-114. 